\title{
CLARICE LISPECTOR: PROCESSOS CRIATIVOS
}

\author{
POR \\ OLGA DE SA \\ Faculdades Integradas Teresa D'Avila, São Paulo
}

O primeiro romance de Clarice Lispector, em 1944, Perto do coração selvagem, projetou-a imediatamente na Literatura Brasileira, como uma ficcionista consciente de seus meios de expressão.

Pretendendo traduzir o que existe de complexo e contraditório no mundo, a romancista teve de violentar a lógica da linguagem, fertilizá-la torná-la adequada e flexível.

Assumindo um ritmo pessoal de narrativa, permeando-a de uma nota poética imprevista, Clarice rompe com a linearidade do romance tradicional, cria uma «estilística das sensações», um dicionário imagético pessoal, articula uma "ordenação estrutural" de seus contos e romances, capaz de questionar concretamente as concepções naturalistas do gênero e de situá-la na mesma linhagem renovadora da literatura universal: de Virginia Woolf, de Joyce e outros.

Mendilow, que analisou longamente o Tristam Shandy, escreveu: «Como Sterne, o escritor de hoje está preocupado com os problemas do tempo na ficção; o que a psicologia associativa de Locke com o seu corolário da 'troca-de-tempo' era para um, a 'durée' de Bergson e a teoria da intuição é para o outro.» Sterne utiliza o contraste entre o tempo real e o ficcional e o termo «digressão» é impróprio para designar seus saltos temporais — pois o Tristam Shandy não tem um ponto fixo de referência, mas todos os tempos dialogam entre si-. Mendilow conclui que até Gide, Proust, Joyce ou Virginia Woolf «não há em ficção qualquer quadro do processo de viver, apanhado no próprio ato de ser, que the seja comparável» ${ }^{1}$.

${ }^{1}$ Adam Abraham Mendilow, O tempo e o romance (Porto Alegre: Globo, 1972), p. 216. 
A técnica de entrelinhas de Sterne é um dos recursos usados por Clarice Lispector, sem falar na intersecção de passado e presente, uma das chaves de leitura da primeira parte de Perto do coração selvagem, na qual se alternam capítulos da infância com os da vida adulta; na segunda parte domina o processo mais refinado já existente na primeira: o passado invade o presente, naturalmente, tal como na vida.

Os problemas gerais da linguagem, da arte, da existência e da morte provocam «digressões» na escritura de Clarice Lispector, retardam a narrativa e são responsáveis por aquele caráter ensaítico que alguns críticos lhe censuram. Nunca, porém, essas «digressões» se caricaturam em dissertações ou assumem forma discursiva. Clarice jamais tenta ganhar o leitor para uma causa. Apenas enuncia. Sua enunciação, pontuada de comparações, de «como se», alonga-se numa tentativa sempre recomençada de atingir uma expressão à altura de sua percepção do mundo, ou melhor, à altura de sua cosmovisão singular e diferenciada.

Nunca tive um só problema de expressão, meu problema é muito mais grave: é o de concepção ${ }^{2}$.

Clarice tem consciência plena de sua técnica de escrever nas entrelinhas e nosso modelo de leitura não pode subestimar esse modo particular de abordagem de sua escritura:

Então escrever é o modo de quem tem a palavra como isca: a palavra pescando o que não é palavra. Quando essa não palavra morde a isca, alguma coisa se escreveu. Uma vez que se pescou a entrelinha, podia-se com alívio jogar a palavra fora. Mas aí cessa a analogia: a não palavra, ao morder a isca, incorporou-a. O que salva então é ler e distraidamente ${ }^{3}$.

Aplicando à ficção clariceana algumas conclusões de Hans Meyerhoff acerca do tratamento do tempo na literatura, podemos focalizar a «relatividade subjetiva» ou a distribuição desigual do tempo em seu primeiro romance. Enquanto o tempo cronológico é objetivo, passível de mensuração, o tempo da experiência pessoal é relativo e irregular, dependendo principalmente os diferentes estados subjetivos» ${ }^{4}$.

Joana-menina, a protagonista, registra essa experiência:

... se tinha alguma dor e se enquanto doía olhava os ponteiros do relógio, via então que os minutos no relógio iam passando e a dor con-

${ }^{2}$ Clarice Lispector, A Legião Estrangeira (Rio de Janeiro: Editora do Autor, 1964), p. 144. Abreviarei: LE.

${ }^{3}$ Clarice Lispector, $L E$, p. 143.

${ }^{4}$ Hans Meyerhoff, O tempo na literatura (Porto Alegre: Globo, 1972), pp. 13-16. 
tinuava doendo. Ou senão, mesmo quando não lhe doía nada, se ficava defronte ao relógio espiando, o que ela não estava sentindo também era maior que os minutos contados no relógio. Agora, quando acontecia uma alegria ou uma raiva, corria para o relógio e observava os segundos em vão ${ }^{5}$.

O que ela sentia, o seu tempo subjetivo de dor ou de «sentir nada» era maior que os minutos do tempo cronológico. Porém, emoções específicas como a alegria e a raiva paralisavam os segundos, já que ela os «observava em vão». Não passavam, eram mais longos que seus próprios sentimentos, maiores que sua capacidade inventiva de encontrar meios para preenchê-los: dançar, inventar palavras, poemas, estórias, armar bonecos de papelão, brincar de cabra cega, «filosofar»e, por fim, chorar sobre o tempo implacável, que não se escoava nunca. Porque era uma menina sozinha.

A narrativa se inaugura com três sons: o tac-tac da máquina de escrever do pai, o tindlen do relógio e o $z z z z z$ do silêncio. E uma grande orelha «cor-de-rosa e morta» à escuta. Instaura-se, desta forma, na narrativa, a subjetividade do seu mundo interior, marcado pelo passado de criança: passado não recordado, mas «presentificado», que ilumina o futuro, pois olhando o grande mundo das galinhas, ela já lhes anuncia o futuro, de galinhas «que-não-sabiam-que-iam-morrer».

Filtra-se, imperceptivelmente na narrativa, o grande caminho da morte, unido à infância, associação indissolúvel que constituirá um dos tons maiores de Perto do coração selvagem.

Há também os momentos parados, «sem nada dentro», brancos, em que Joana se põe à espera. Até que de repente se «dê corda» ao dia. A metáfora transfere os processos mecânicos para a realidade viva, como se o fluir do tempo cronológico fosse criado pela subjetividade da menina, e tudo começasse a funcionar, «as coisas revivendo cheias de pressa como uma chaleira a ferver» ${ }^{6}$. Sem o tin-dlen do relógio que naturalmente só se ouvia a intervalos.

Enjoava de tanta vida borbulhando e procurava surpreender o momento seguinte, no seu próprio acontecer. Porém, a espera subjetiva e sua urgente expectativa corroíam, antecipadamente, o ser das coisas futuras:

E sempre no pingo de tempo que vinha nada acontecia se ela continuava a esperar o que ia acontecer, compreende? ${ }^{7}$

${ }^{5}$ Clarice Lispector, Perto do coração selvagem, 3." edição (Rio de Janeiro: Editora Sabiá, 1969), p. 12. Abreviarei: PCS.

${ }^{6}$ Clarice Lispector, PCS, p. 9.

7 Ibid., p. 10. 
O tempo experimentado pela mente humana tem a qualidade de fluir, e embora os momentos sucessivos e escoem, constantemente, o fluir perdura, no seio da própria mudança. Este aspecto se liga à dimensão psicológica da.memória, como instrumento de registro dinâmico dos acontecimentos.

As coisas lembradas são fundidas e confundidas com as coisas temidas e com aqueles que se tem esperança de que aconteçam. Desejos e fantasias podem não só ser lembrados como fatos, como também os fatos lembrados são constantemente modificados, reinterpretados e revividos à luz das exigências presentes, temores passados e esperanças futuras ${ }^{8}$.

Não só os sonhos sofrem os processos de condensação e deslocamento apontados por Freud. A memória também. Os fatos lembrados se confundem e se interpenetram e embora exista uma ordem subjacente subjetiva, essa ordenação parece caótica e confusa, comparada com a ordem do tempo cronológico. Certamente na duração do tempo interior existe uma lógica interna, que é percebida como uma espécie de ilogismo. Ninguém se lembra das coisas linearmente. Os processos que Freud privilegia ao tratar dos sonhos, também se aplicam à memória involuntária e mesmo à voluntária. A reescritura da memória tem seus pontos de condensação, suas ubiqüidades, seus saltos e deslocamentos. Passado remoto e passado próximo, passado e presente se misturam e a chamada «lógica das imagens». é regida por associações significativas para o sujeito, mas nem sempre facilmente acessíveis a uma análise que busque nexos causais externos.

A estruturação da primeira parte de Perto de coração selvagem obedece a esse processo, que começa por desnortear as expectativas do leitor. $\mathrm{O}$ primeiro capítulo chama-se «O pai», mas podia também chamar-se «O dia de Joana-menina»: um longo dia em que Joana constantemente redimensiona o tempo cronológico, comparando-o com o set tempo interior.

O segundo capítulo intitula-se "O dia de Joana». $\hat{E}$ um dia da vida de Joana casada. Ela continua, porém, nos momentos de ausência do marido, a «viver o fio da infância».

Esse tênue fio da infância, tecido de fatos filtrados pela memória e, à vezes, inventados, atravessa toda a narrativa, como uma espécie de memória involuntária, ao sabor das associações que o presente propicia.

${ }^{8}$ H. Meyerhoff, op. cit., p. 20. 
Ela nem precisa ter saudades da infância:

-Não é saudade, porque eu tenho agora a minha infância mais do que enquanto ela decorria...» ${ }^{9}$.

O passado da protagonista não se confina nos capítulos que lhe são destinados, mas invade, sob forma de sensações, o presente transformado já em futuro que, por sua vez, se torna passado, num fluir incessante. De modo que o próprio passado já nem tem explicação cabal; contaminase pelo mistério do futuro, sempre contido em seu bojo. A protagonista pergunta-se se não vive as mesmas coisas em situações diversas.

Silenciou de novo olhando para dentro de si. Lembrou-se: sou a onda leve que não tem outro campo senão o mar, me debato, deslizo, vôo, rindo, dando, dormindo, mas ai de mim sempre em mim, sempre em mim. De quando era aquilo? Lido em criança? Pensado? De súbito recordou-se: ainda agora pensara-o, talvez antes de encostar o braço no de Otávio, talvez naquele momento em que tivera vontade de gritar... Cada vez mais tudo era passado... E o passado tão misterioso como o futuro... ${ }^{10}$

Joana se reconhece e se identifica nas sensações que a invadem, mas nem sempre distingue os fatos acontecidos, no passado, dos próprios pensamentos e imaginações. Mais ainda: desloca, por vezes, pensamentos recentes para o passado remoto, e, só com esforço, consegue situar-se no passado mais próximo, que acabou de ser o seu presente.

O tempo é carregado de «significação» para o homem, porque a vida humana é vivida à sombra do tempo: porque a pergunta "o que sou» apenas faz sentido em termos do que «em que me tenho tornado», isto é, em termos de fatos históricos objetivos juntamente com o modelo de associações significativas, constituindo a biografia ou a identidade de «eu» ${ }^{11}$.

A narradora de Perto do coração selvagem reconstrói uma identidade: a de Joana. A reconstrução, porém, não se faz linearmente. Aliás, Joana não tem biografia. Já se disse que a fabulação se rarefaz, nos romances de Clarice Lispector. Em benefício de quê? Neste caso, principalmente, em benefício da densidade metafísica da pesquisa do tempo. Os fatos são insignificantes, no mais exato sentido etimológico.

${ }^{9}$ Clarice Lispector, PCS, p. 44.

${ }^{10}$ Ibid., p. 133.

${ }^{11}$ H. Meyerhoff, op. cit., p. 25 
Neste instante mais desperta, se quisesse, com um pouco mais de abandono, Joana poderia reviver toda a infância... O curto tempo de vida junto ao pai, a mudança para a casa da tia, o professor ensinandoThe a viver, a puberdade elevando-se misteriosa, o internato... O casamento con Otávio... Mas tudo isso era muito mais curto, um simples olhar surpreso esgotaria todos esses fatos ${ }^{12}$.

O leitor também poderia, num átimo, repassar o resto da história: o tédio do casamento, a decepção com o professor, o encontro com Lídia, com o amante, a partida de todos os homens e a viagem. Viagem em busca de si mesma. Fechados os círculos de sua vida, Joana se entrega, no longo monólogo final, à busca de sua identidade.

O começo de tudo está lá, nos dias da infância. A tia, chamando-a de víbora, predestina-a para os dias futuros, em que Lídia e Otávio também a chamarão assim.

O mar é um apelo para a viagem final, em busca do selvagem coração da vida, cuja pulsação ela já conhecera.

É claro que, nesta pesquisa da própria identidade, não podia faltar a quem, desde criança, passava um dia inteiro brincando com a palavra «nunca», a indagação a respeito do mistério das palavras. Esta indagação reaparece, muitas vezes, na ficção clariceana, até constituir a trama de seus últimos livros: A hora da estrela (1978) e Um sopro de vida (1979, póstumo). A ficcionista do tempo é também uma questionadora da ficção. Entre a ficção e a vida, ela sempre se perguntou se depois de escrever ainda teria do que viver. Tentando encontrar a vida em si mesma, ela temia apoiar-se demais no jogo da arte, que é eterno no seu fluir.

Meyerhoff cita esta incomparável afirmação de Proust:

Um único minuto libertado da ordem cronológica do tempo recriava em nós o ser humano similarmente libertado.

E comenta:

O que Proust queria dizer era que o evento isolado lembrado em toda a sua riqueza qualitativa e realidade concreta parecia estar libertado da data que tinha originalmente na ordem cronológica do tempo: e que o mesmo vale para o eu recriado imaginativamente através desse ato de recordação ${ }^{13}$.

${ }_{12}$ Clarice Lispector, PCS, p. 20.

${ }^{13} \mathrm{H}$. Meyerhoff, op. cit., pp. 48-49. 
A eternidade não é algo de abstrato e frio, mas um momento concreto e singular, um «agora» permanente, que anulando o próprio tempo pela presentificação, quase confere à memória o fluir da própria duração.

O capítulo «As alegrias de Joana», que só tem seis páginas, poderia resumir-se assim: as alegrias de Joana são seus momentos eternos. Captar o eterno sob o fluir, eis uma de suas ocupações favoritas. Epifanias. «Eterno» e «transeunte»: o contraste se resolvendo em síntese.

A impressão de que se conseguisse manter-se na sensação por mais uns instantes teria uma revelação -facilmente, como enxergar o resto do mundo apenas inclinando-se da terra para o espaço. Eternidade não era só tempo, mas algo como a certeza enraizadamente profunda de não poder contê-lo no corpo por causa da morte... ${ }^{14}$

Eternidade é, paradoxalmente, sucessão fixada no seu suceder, porque o movimento é que explica a forma. Joana está toda do lado de quem sente o fluir não logicamente apreensível da realidade, transformando em absoluto o instante fugidio. No pólo da sensação e não da inteligência se pode pulsar como um cavalo novo na cavalgada para o núcleo do existir. As sensações de glória são sensações puras em que o entendimento não pode dissolver o mistério da plenitude sentida. A epifania é, pois, um momento de visão. Mas nada tem a ver com a inteligência racionalizadora. Tem a ver com a imaginação, fonte de criação. Joana sabe que o ver, o lance visionário, o seu, nunca será religioso. Será um ver pela primeira vez, embora já tenha olhado antes. Esta capacidade reconquistada de ver é própria da sensação e, no entanto, colhe a essência, a marca da existência. Acaba-se por descobrir empiricamente que «tudo é um», a identidade dinâmica de todos os seres. Joana atinge o cerne do ser, pela imaginação.

Segundo Pouillon, a imaginação é uma forma de conhecimento do eu. Uma forma criadora; Joana também sabe que inventa. Sabe que inventar é criar e, se alguma vez chama isso de «mentira», é porque assume ironicamente o «bom senso» das pessoas banais (o marido, a tia) para desmantelá-lo.

Havia muitas sensações boas. Subir o monte, parar no cimo e, sem olhar, sentir atrás a extensão conquistada, lá longe a fazenda. $O$ yento fazendo esvoaçar as roupas, os cabelos. Os braços livres, o coração fechando e abrindo selvagemente, mas o rosto claro e sereno sob o sol. E sabendo principalmente que a terra embaixo dos pés era tão profunda

${ }^{14}$ Clarice Lispector, PCS, p. 39. 
e tão secreta que não havia a termer a invasão do entendimento dissolvendo seu mistério. Tinha uma qualidade de glória esta sensação ${ }^{15}$.

A epifania é, assim, integrada à visão que Clarice Lispector tem de êxtase e lances brilhantes que gerem uma alegria sensível.

$O$ termo epifania vem da esfera religiosa e significa manifestação, aparição, irrupção de Deus no mundo ante os olhos dos homens, sob formas sensiveis. Repentinamente. $O$ ponto alto das manifestações de Deus no Antigo Testamento, é o acontecimento do Sinai, com sinais extraordinários, relâmpagos e trovões. No Novo Testamento há aparições de anjos, do Espírito Santo e de Jesus Cristo. A epifania constitui, portanto, uma realidade complexa, perceptível aos sentidos, sobretudo aos olhos (visões), ouvidos (vozes) e até ao tato (Gn 32,24; Jo 20,22). Não existem epifanias mudas. A palavra está sempre no centro da manifestação de Deus. Escondido talvez, sua voz ecoa através da sarça ardente (Ex 3), do ciciar do vento (1 Rs 19,13) e da nuvem (Mc 9,7).

Joyce transforma essa revelação em técnica literária. Rastreamos, em outro momento, a evolução da técnica epifânica em Joyce, desde o Stephen Hero até Finnegans Wake ${ }^{16}$.

$\hat{\mathrm{E}}$ evidente, até certo ponto, a analogia do procedimento em Joyce e Clarice, sem que por isso tenhamos de palmilhar o escorregadío terreno da «crítica de influências».

O título do primeiro livro de Clarice, Perto do coração selvagem, inspira-se em The Portrait of the Artist as a young Man e diz textualmente: of life.

He was alone. He was unheeded, happy and near to the wild hearth

O texto precede a uma das mais características epifanias de Joyce: o episódio da menina-pássaro ${ }^{17}$.

Clarice privilegia esse momento da obra de Joyce na sua própria inauguração como romancista. Jamais, porém, usa o termo epifania e se tem consciência do processo, não o demonstra explicitamente. O capítulo «... o banho...», um dos pontos altos de seu primeiro livro, nos remete, por vários traços, se bem que em situação diversa, ao episódio paradigmal da moça-na-água de Joyce.

${ }^{15}$ Ibid., pp. 40-41.

${ }^{16}$ Olga de Sá, A escritura de Clarice Lispector (Petrópolis: Vozes, 1979), cap. IV.

17 James Joyce, The Portrait of the Artist as a Young Man (New York: The Viking Press, 1949), pp. 431-432. 
A água cega e surda, mas alegremente não-muda brilhando e borbulhando de encontro ao esmalte claro da banheira, o quarto abafado de vapores mornos, os espelhos embaçados, o reflexo do corpo já nu de uma jovem nos mosaicos úmidos das paredes.

A moça ri mansamente de alegria de corpo. Suas pernas delgadas, lisas, os seios pequenos brotaram da água. Ela mal se conhece, nem cresceu de todo, apenas emergiu da infância. Estende uma perna, olha o pé de longe, move-o terna, lentamente como a uma asa frágil. Ergue os braços acima da cabeça, para o teto perdido na penumbra, os olhos fechados, sem nenhum sentimento, só movimento. O corpo se alonga, se espreguiça, refulge úmido na meia- escuridão-é uma linha tenșa e trêmula. Quando abandona: os braços de novo se condensa, branca e segura. $\mathrm{Ri}$ baixinho move o longo pescoço de um a outro lado, inclina a cabeça para trás -a relva é sempre fresca, alguém vai beijá-la, coelhos macios e pequenos agasalham-se uns nos outros de olhos fechados. - Ri de novo, em leves múrmurios como os da água. Alisa a cintura, os quadris, sua vida ${ }^{18}$.

O espaço e a natureza deste artigo não nos permitem citar o texto inteiro. Temos de retalhá-lo. Predominam, nele, sensações táteis e, entre elas, especificamente as sensações térmicas derivadas da água: vapores mornos, umidade, espelhos embaçados. A moça é só movimento. Sua alegria é pura sensação corporal. Os seios e as pernas brotam da água. O símile que compara o pé a uma asa frágil nos leva a pensar em bailarina e pássaro. As sensações térmicas exprimem e acalentam a sensualidade nascente: por associação de movimentos, quando a moça inclina a cabeça para trás, lembra o frescor da relva e espera o beijo. $\mathrm{Na}$ relva, os pequenos coelhos. As sensações ganham então calor animal; a maciez e o aconchego dos pelos, apenas adivinhados, sugerem o corpo nascente da mulher. Fundem-se o movimento e o tato e a moça alisa sua própria vida metonimicamente significada pelos quadris. As sensações produzidas pela água morna, que lhe abraça o corpo o sobre ele pesa, expressas por um novo símile -lembram o mar-. A invasão da maré no corpo da moça é uma metáfora do ritual da fecundação, da iniciação para vida, tangível agora, na alegria da puberdade.

Aliás, mulher e o mar é uma das imagens recorrentes na ficção da Clarice Lispector: Joana e o mar, Lóri e o mar em Uma aprendizagem.

Ali estava o mar, a mais ininteligível das existências não-humanas. E ali estava a mulher, de pé, o mais ininteligível dos seres vivos. Como o ser humano fizera um dia uma pergunta sobre si mesmo, tornara-se

\footnotetext{
${ }^{18}$ Clarice Lispector, PCS, p. 61.
} 
- mais ininteligível dos seres onde circulava sangre. Ela o e mar (...).

Vai entrando. A água salgadíssima é de um frio que lhe arrepia e agride em ritual as pernas.

Mas uma alegria fatal -a alegria é uma fatalidade- já a tomou, embora nem lhe ocorra sorrir. Pelo contrário, está muito séria. O cheiro é de uma maresia tonteante que a desperta de seu mais adormecido sono secular (...).

O caminho lento aumenta sua coragem secreta - e de repente ela se deixa cobrir pela primeira onda! $O$ sal, o iodo, tudo líquido deixamna por uns instantes cega, toda escorrendo espantada de pé, fertilizada ${ }^{19}$.

São inúmeras as epifanias de beleza nos romances e contos de Clarice: os cavalos brancos, a pantera, o vento, os amantes, enfim todos os intervalos da vida que a preenchem e dela transbordam.

Mas seus momentos epifânicos não são necessariamente transfigurações do banal em beleza. Muitas vezes, como marca sensível da epifania crítica, surge o enjôo, a náusea.

Mesmo no episódio do «banho» acima referido, há também sensações desagradáveis.

Quando emerge da banheira é uma desconhecida que não sabe o que sentir. Nada a rodeia e ela nada conhece. Está leve e triste, move-se lentamente, sem pressa por muito tempo. O frio corre com os pés gelados pelas suas costas mas ela não quer brincar, encolhe o torso ferida, infeliz. Enxuga-se sem amor, humilhada e pobre, envolve-se no roupão como em braços mornos. Fechada dentro de si, não querendo olhar, ah, não querendo olhar, desliza pelo corredor - a longa garganta vermelha e escura e discreta por onde afundará no bojo, no tudo. Tudo, tudo, repete misteriosamente ${ }^{20}$.

Vislumbra-se a crise da identidade, quando a menina, emergindo da infância, não se reconhece. Essa crise, acumulando-se, provoca um questionamento progressivo e as sensações de desconforto. Nesse instante, desconhecendo-se, estranhando seu próprio sentir, a crise da própria identidade coincide com o corte do frio, que lhe fere o dorso.

O texto não cabe todo numa epifania da visão reveladora, embora dela ostente a graça e o brilho.

$O$ estado final que Joana atinge é-nos oferecido ao nível do corpo, por sensações cromáticas: o vermelho, o escuro, indicam o sangue púbere, que inauguram a vida de mulher.

${ }^{19}$ Clarice Lispector, Uma aprendizagem ou o livro dos prazeres, 2. ${ }^{a}$ edição (Rio de Janeiro: Sabiá, 1970), pp. 83-84.

${ }^{20}$ Clarice Lispector, PCS, pp. 61-62. 
A adjetivação negativa indicia uma epifania crítica, que operativamente se construiu pela linguagem. Uma antiepifania corrosiva da primeira irrupção epifânica.

O movimento unido ao tato, no ato de enxugar-se, acompanha-se de emoções, que marcam estados negativos: a moça está leve e triste, infeliz, humilhada, sem amor por si mesma. Os movimentos, antes vivos e gentis, se ralentam. Morreu a infância. A moça não quer brincar. Ao calor, seguese o frio. Ferida no dorso, sem cabeça e sem membros, ela é só um tronco de mulher. A sensação de calor que a envolve, já não é animal, mas the vem dos braços mornos do roupão. Seu movimento deslizante pelo corredor, até o quarto de dormir, é o deslizar do próprio sangue, pelas paredes íntimas de seu corpo. Ela mesma desliza inteira pela sua natureza desconhecida de mulher, ela mesma se afunda pela garganta escura e discreta, no bojo da vida.

A transfiguração epifânica nem sempre é radiosa, mas se faz também no sentido do mole, do engordurado, do demoníaco.

Um dia, antes de casar, quando sua tia ainda vivia, vira um homem guloso comendo. Espiara seus olhos arregalados, brilhantes e estúpidos, tentando não perder o menor gosto do alimento. $E$ as mãos, as mãos. Um delas segurando o garfo espetado num pedaço de carne sangrenta -não morna e quieta, mas vivíssima, irônica, imoral--, a outra crispando-se na ânsia de já comer novo bocado. A ferocidade, a riqueza de sua cor... Avermelhada nos lábios e na base do nariz, pálida e azulada sob os olhos miúdos. Joana estremecera arrepiada diante de seu pobre café. Mas não saberia depois se fora por repugnância ou por fascínio e voluptuosidade. Por ambos certamente. Sabia que o homem era uma força ${ }^{21}$.

Ela vislumbra nessa violência a vida, o gosto do mal. Portanto, assim como existe na obra de Clarice toda uma gama de epifanias da beleza e da visão, existe também uma outra, de epifanias críticas e corrosivas, epifanias das percepções decepcionantes, seguidas de náusea ou tédio; os seios flácidos da tia que a acolhem depois da morte do pai, o professor hipocondríaco rodeado de chinelos e remédios, a barata, massa informe de matéria viva, em que G. H. experimenta o gosto insosso do ser.

Conclui-se que a epifania constitui não simplesmente uma técnica, um motivo ou um tema da ficção clariceana. Integrada à sua visão do mundo, é um procedimento de estranhamento, no sentido que Chklósvki deu ao termo:

${ }^{21}$ Ibid., p. 15. 
O objetivo da arte é dar a sensação do objeto como visão e não como reconhecimento; o procedimento da arte é o procedimento do estranhamento dos objetos, é o procedimento que consiste em obscurecer a forma, aumentar a dificuldades e a duração da percepção. $O$ ato de percepção em arte é um fim em si mesmo e deve ser prolongado; a arte é um meio de experimentar o devir do objeto, o que já é "passado» não importa para a arte 22 .

A visão é concreta, poética. Libra-nos do automatismo perceptivo enfraquecido pelo hábito, devolve-nos a sensação de vida.

A epifania é expressão de um momento excepcional, em que se rasga para alguém a casca do cotidiano, que é rotina, mecanicismo e vazio. Mas é também defesa contra os desafios das descobertas interiores, das aventuras com 0 ser. Por isso a epifania é sempre um momento de perigo, à borda do abismo, da sedução que espreita todas as vidas. A vida protegida representa o domesticado, o dia-a-dia, o casamento, as compras na feira, as visitas e os aniversários. A casca desse atos rotineiros está sempre por um fio e seu rompimento se dá num momento epifânico: uma mulher volta das compras e, num átimo, vislumbra o automatismo da própria vida, nos gestos de um cego, que masca chicles; outra transpõe o umbral da loucura ante a perfeição das rosas sobre a mesa; uma galinha recupera, por minutos, sua ancestral natureza selvagem e mobiliza o caçador que existe no homem civilizado dos almoços de domingo. Enfim, a epifania é um modo de desvendar a vida selvagem que existe sob a mansa aparência das coisas, é um pólo de tensão metafísica, que perpassa ou transpassa a obra de Clarice Lispector. As personagens de seus três primeiros romances vivem essa tensão por dentro e por isso talvez pareçam irreais e incoerentes. Enfeitiçadas pelo avesso do cotidiano, psiquês mergulhadas na tessitura profunda do ser, seu destino deveria parecer incomum.

São personagens incômodas e Joana chega a ser inconfortável. A romancista, marcada pela desconfiança do sentimental e patético, também não se resigna a dar-lhes um destino invulgar. Joana simplesmente viaja, consumida por dentro pela ânsia, que o monólogo final, o seu de profundis nos confirma; Virgínia morre, sem destaque, atropelada por um carro, julgada uma prostituta vulgar; Lucrécia desaparece na viuvez, esperançosa de um novo pretendente.

Martim, o único personagem masculino de sua travessia, depois das paisagens míticas que ontologicamente transpõe, acaba passivo na mão

${ }^{22}$ Cf. Chklóvski, «A arte como procedimento», em Teoria da literatura: formalistas russos (Porto Alegre: Globo, 1971), p. 45. 
da polícia. Nenhum deles consegue romper, definitivamente, a casca da vida. Se deixarmos G. H. perdida nos labirintos de sua mística adoração, no fim do romance que termina em travessóes, para a reencontrarmos no princípio da obra que se inicia com travessões, em ansiosa busca, restamnos Ulisses e Lóri. Mas como decidir até que ponto eles representam o fim de um itinerário ou a sua paródia? Aprenderam a amar, aprenderam o prazer, aprenderam a ser felizes. No universo romanesco de Clarice, se esta perspectiva não constituir propriamente uma paródia, será, ao menos, uma pausa, um respiro necessário para celebrar a alegria. Não é, porém, uma resposta. Aliás $O$ Livro dos prazeres começa com uma vírgula e termina com dois pontos. Uma vírgula é uma pausa. Pode-se respirar. Dois pontos jamais significam final de discurso. Anuncian, sempre, que não está fechado o processo de enunciação, algo vem depois. Depois da aprendizagem do amor e de ser feliz, o que virá?

Virá essa perpétua aventura de escrever, talvez para Clarice Lispector a forma pessoal, a única que lhe é possỉvel, de comunicar a própria visão. Visão que a transforma numa ficcionista sempre à beira do ser, o qual ela não poder decifrar por outras vías como a filosofia, a pintura, a mística ou alguma religião. Sua forma específica é escrever. Não lhe é fácil encontrar uma concepção ficcional adequada à sua visão dos homens e das coisas. Qual demiurgo, ela cria personagens comuns, devorados por uma ânsia encoberta sob cinzas. Vira a revira o seu enigma, tentando decifrá-lo em linguagem. Oscila entre personagens que vislumbram o «por dentro» das coisas, como Joana, Virgínia, Martim ou G. H.; ou personagens que só "vêem» de vez em quando, protegidos que estão pela malha do tecido comum: Ana, a aniversariante, a adolescente de São Cristóvão.

Está sempre à espreita da romancista a tentação do silêncio, como única expressão digna e adequada dessa outra face do ser; porque o silêncio não trai, porque o silêncio não diz de menos, porque o silêncio é, em certo sentido, absoluto. Porque ele não participa da natureza escorregadia e indomável da palavra, este ser de som que tem sempre «uma porta disfarçada», por onde se pode escapar.

Não parece relevante relacionar esta cosmovisão de Clarice Lispector com a filosofia existencialista ou com uma crítica da vivência do homem nas megalópolis do mundo moderno.

Pode ser que essa vivência tenha contribuído para aguçar-lhe a percepção do mundo; seus personagens podem ter sido extraídos desse magma de frustrações e anseios, no qual mergulha o homem do século xx. Porém, sua abordagem é mais radical: sonda o homem, circunstanciado ontem e hoje, imprevisível sempre. O mundo moderno representa um agudo momento cultural da opacidade do cotidiano, da mecanização da 
vida que a todos consome. Mas, substancialmente, essa tensão metafísica, desde Prometeu, é atemporal e a-espacial.

Tem razão, portanto, Alfredo Bosi, quando, ao comentar a obra da ficcionista, sobretudo A Paixão segundo G. H., situa este romance a nível do metafísico, como um salto do psicológico, salto plenamente amadurecido na consciência da narradora. Ele cita $A$ Paixão:

Além do mais a "psicologia» nunca me interessou. O olhar psicológico me impacientava e me impacienta, é um instrumento que só transpassa. Acho que desde a adolescência eu havia saído do estágio do psicológico ${ }^{23}$.

Nessa «obra aberta» de educação existencial, como Bosi caracteriza $A$ Paixão, esgotam-se os recursos habituais do romance psicológico. $\mathrm{O}$ monólogo de G. H., entrecortado de apelos a um ser ausente, uma obra sem começo definido, sem epílogo repousante, não exprime etapas de um drama psicológico, mas o contínuo existencial, que busca a comunhão do ser com o ser ${ }^{24}$.

Sendo a problemática de Clarice Lispector uma «indagação ontológica», escapa ao enfoque autobiográfico e ao psicológico, articulado nas relações de subjetividade, mesmo quando ela usa a $1 .^{a}$ pessoa do singular. Isto reforça a perspectiva já delineada de que sua fição aponta decididamente para o metafísico.

As relações de subjetividade se criam para conferir dramaticidade à narrativa. Filtram-se em Joana, Virginia, Martim, as indagações da ficcionista, marcadas pela sua particular maneira de ver e sentir. Daí a importância do monólogo interior e do discurso indireto livre, em seu estilo. O monólogo representa um mergulho no fluxo de consciência das personagens para colher a gênese dos pensamentos e sentimentos, coordenadas do mesmo dualismo interior em que parece debater-se a romancista: o desejo de viver ou analisar a consistência da vida; participar do sangue grosso da existência ou atirar-se no jogo da escritura. A fábula se rarefaz, mas a trama se condensa e avança, levada pelos elementos dramáticos que o monólogo veicula, enquanto é um diálogo interiorizado e se dirige implicitamente ao «tu» do leitor.

$\mathrm{Na}$ verdade, o monólogo, sobretudo em ficção, continua a ser um diálogo, ao menos implícito, pois subentende a presença do leitor, real

${ }^{23}$ Clarice Lispector, A Paixão segundo G. H., 3. edição (Rio de Janeiro: Sabiá, 1972), p. 26. Abreviarei: PSGH.

${ }^{24}$ Cf. A. Bosi, História concisa da Literatura Brasileira (São Paulo: Cultrix, 1970), pp. $475-478$. 
ou virtual. A própria personagem, que monologa, se desdobra em duas entidades mentais: o «eu» e o «outro», um «eu» que fala e o mesmo «eu» que se ouve, como se fosse um «outro».

Para muitos leitores, essa perspectiva parece monótona. Resgata-se, neste caso, a monotonia com a profundidade e a riqueza, porque este é um modo fundamental de colher, ao vivo, as indagações íníimas do homem a respeito do ser.

Existe um modo de utilizar a linguagem, que Jakobson chamou metafórico, o qual elege as operações de seleção e substituição, em oposição ao modo metonímico, que valoriza os aspectos contextuais de combinatórios.

O estilo de Clarice Lispector revela-se centrado no pólo metafórico da linguagem. Predominam nele as operações situadas no eixo da seleçãosubstituição. A metáfora estranhada, oposta aos lugares-comuns, constitui um momento privilegiado na escritura de Clarice Lispector. Há, no seu texto, preferência pelos jogos metafóticos, em que se criam as associações de similaridade, em prejuízo das operações estilísticas, fundadas na contiguidade. $\hat{\mathrm{E}}$ claro que as duas atitudes não se excluem, mas, como diz Jakobson, manipulando esses tipos de conexão, uma pessoa revela suas predileções espontâneas e seus esforços voluntários. Manifesta-se um modo todo pessoal de estruturar a frase e o discurso, de organizar a sintaxe, de dar relevo a certos aspectos da enunciação.

Sensível e alerta em relação às oposições e semelhanças que constituem elementos da complexidade do mundo, o estilo de Clarice é pontuado de contrastes e analogias, que se traduzem, os primeiros, em oxímoros e paradoxos, e as segundas, em comparações e metáforas.

A retórica tradicional classifica o oxímoro e o paradoxo como variantes da antítese, refletindo uma realidade múltipla e contrastante, que corresponda, no espírito humano, à necessidade de compreender uma idéia por oposição a outra. Dubois, na sua Retórica Geral, coloca o oxímoro no mesmo compartimento da antifrase, considerando sua aproximação da antítese como fantasia, pois esta é um metalogismo, por repetição, do tipo: A não é não-A.

O oxímoro é uma «coincidentia oppositorum»: uma contradição que a antítese «tragicamente proclama» e o oxímoro "paradisiacamente assume». É o caso dos oxímoros de Camões, no soneto "Amor é fogo que arde sem se ver» e da célebre oração de S. Francisco de Assis: «É morrendo que se vive», etc.

A colocação de Dubois situa o oxímoro no eixo da seleção-substituição, isto é, no eixo da metáfora. Aliás, o estilo de Clarice Lispector está 
cheio de estranhezas, de paradoxos, de expressões que, parecendo formular evidências, manifestam a face chocante do óbvio:

E voltei a ser uma pessoa que nunca fui. Voltei a ter o que nunca tive: apenas as duas pernas ${ }^{25}$.

Escrever é tantas vezes lembrar-se do que nunca existiu ${ }^{26}$.

Os símiles ou comparações exprimem também essa atitude de estranhamento, que torna a sua imagética insólita e, por vezes, desafia a compreensão do leitor, que não pode entregar-se, diante de seu texto, a nenhuma espécie de fácil deleite. Alguns exemplos de Perto do coração selvagem: ver (p. 9).

... as coisas revivendo cheias de pressa como uma chaleira a fer... o desejo de agradar e de ser amada por algém poderoso como a tia morta (p. 15).

... como se ela tivesse jogado uma brasa ao marido, a frase pulava de um lado para outro (p. 29).

Ela trabalha muito na clave do «como» e do «como se». Em $A$ maça no escuro, essa técnica, pela insistência e multiplicidade, chega ao desgaste da expressão, procurando esgotar inúmeras possibilidades de aproximação, todas frustradas pelo indizível, «como se» o itinerário expressivo do romance realizasse o que Martim não realizou. Ele começa do zero da linguagem para reconstruir-se lentamente como homem e como palavra. O romance perfaz-se em centenas de páginas para terminar numa espécie de zero expressivo, que aspira doloridamente ao silêncio:

Porque eu, meu filho, eu só tenho fome. E esse modo instável de pegar no escuro uma maçã — sem que ela caia ${ }^{27}$.

Há também no estilo de Clarice uma espécie de talento visual e plástico, quanto ao modo de criar a paisagem e o ambiente das personagens:

$\hat{E}$ o que Martim viu foi uma estendida planície vagamente em subida. Muito além começava um declive suave que, pela graça de suas linhas, prometia deslizar para um vale ainda invisível. E no fim do si-

${ }^{25}$ Clarice Lispector, PSGH, p. 8.

${ }^{26}$ Clarice Lispector, $L E$, p. 143.

${ }^{27}$ Clarice Lispector, A maçã no escuro, 3. edição (Rio de Janeiro: J. Álvaro, Editor, 1970), p. 257. Abreviarei: $M E$. 
lêncio do sol, havia aquela elevação adoçada pelo ouro, mal discernível entre brumas ou nuvens baixas, ou talvez pelo fato do homem não ter ousado pôr os óculos. Ele não sabia se era montanha ou apenas névoa iluminada ${ }^{28}$.

Dir-se-ia que, neste caso, ela trabalha numa clave aproximativa, conforme sua luz interior, e vai tentando por meio de certa modalidade de técnica impressionista, de comparações e repetições, adequar a nuança da cor do quadro ao seu instante de luz.

De outras vezes, Clarice manipula grandes massas de tinta, a pastel, expressionisticamente lambuzando a tela, dando ao leitor a sensação rastejante da vida:

Porque, qualquer que tivesse sido a sua época de glória e viço, agora o terreno tinha o silêncio do que é entregue a si mesmo. Havia algumas pedras cinzentas e duras. Um pedaço de tronco deitado. Raízes expostas de uma árvore havia muito tempo cortada, pois nenhuma umidade porejava mais no corte oblíquo. Ervas cresciam verticais. Algumas haviam atingido uma altura que já as tornava sensíveis à brisa adstringente da aurora. Outras eram rasteiras e coladas ao chão, e deste não se arrancariam sem morte. Terra grossa se esfarelava junto de um formigueiro; era uma desordem tranqüila ${ }^{29}$.

Se por vezes Clarice usa da frase fragmentária; em outras, a frase se amplia e abusa do processo sindético construído com a conjunção «e», que certos estudiosos costumam acusar de enfraquecer o estilo.

E lá era bom. Lá nenhuma planta sabia quem ele era; e ele año sabia quem ele era; e ele não sabia o que as plantas eram; e as plantas não sabiam o que elas eram. $\mathrm{E}$ todos no entanto estavam vivos quanto se pode estar vivo... ${ }^{30}$.

Clarice parece fazer da repetição da coordenativa «e» não um processo enfático, mas, ao contrário, a procura de um efeito de desgaste da palavra e da frase.

A escritora não tem medo desse desgaste. Assume-o, realmente, como uma técnica e um gosto pessoal:

... a repetição me é agradável, e repetição acontecendo no mesmo lugar termina cavando pouco a pouco, cantilena enjoada diz alguma coisa ${ }^{31}$.

${ }^{28}$ Clarice Lispector, $M E$, p. 63.

${ }^{29}$ Ibíd., p. 63.

${ }^{30}$ Ibid., p. 70.

${ }^{31}$ Clarice Lispector, $L E$, p. 175. 
Toma sobre si esse processo redundante, visando porém a dizer alguma coisa, por meio da "cantilena enjoada».

Era a segunda vertigem naquele dia! Sim, era a segunda vertigem. naquele dia! Como um clarim... Fitou-os intensamente. Vou embora dessa casa, gritou-se agitada. E cada vez mais a sala se fechava, de um. momento para outro despertaria a fúria no homem e na mulher! Como. a chuva que rebenta, como a chuva que rebenta... ${ }^{32}$

Esta redundância, cujo aspecto positivo já foi recuperado por Luís Costa Lima e por Benedito Nunes como «construção de uma prosa mais afim do poético» ${ }^{33}$, tem, portanto, alto teor de informação estética, segundo a terminologia de Max Bense.

Haroldo de Campos ressaltou, a propósito de Carlos Drummond de Andrade, a utilização expressiva de uma «escandalosa técnica de repetições» no poema "No meio do caminho», «composição que se tornou emblemática não só de sua poesia mas de toda uma fase heróica do nosso modernismo» ${ }^{34}$.

Haroldo de Campos indica também o fato de Bense reavaliar o mesmo problema no estilo de Gertrud Stein, evidenciando como o seu experimentalismo, injustamente olvidado, fizera da repetição um dos princípios de sua invenção estética ${ }^{35}$.

Sem entrar nas discussões que uma definição de estilo acarreta, digamos ser o estilo de um autor sua escolha e organização pessoal de certo número de disponibilidades contidas na língua. Max Bense escreve, nos termos de sua estética informacional estatística, que toda "concepção e produção consciente de um estado estético ou de um objeto artístico parte de um repertório» ${ }^{36}$.

O repertório é seletível. Os estados estéticos, por exemplo, a sequência de palavras num texto, são determinados de forma pessoal ou singular. $\hat{E}$ claro que a criatividade, a originalidade, a inovação dependem do repertório, devendo ser encaradas de modo relativo. Na Estética bensiana, o termo «estilo» significa redução à ordem e, portanto, implica redundância ${ }^{37}$.

${ }^{32}$ Clarice Lispector, PCS, p. 57.

${ }^{33}$ Luís Costa Lima e Clarice Lispector, em A Literatura no Brasil, vol. V (Rio de Janeiro: Editorial Sul Americana, 1970), pp. 452-453.

${ }^{34}$ Haroldo de Campos, Metalinguagem: ensaios de teoria e crítica literária (São Paulo: Cultrix, 1976), p. 40.

${ }^{35}$ Cf. Haroldo de Campos, op. cit., p. 14.

${ }^{36}$ Max Bense, Pequena estética (São Paulo: Perspectiva, 1971), p. 67.

${ }^{37} \mathrm{Cf}$. Max Bense, op. cit., p. 32. Para Bense, «O estilo não se baseia no montante de inovação, nem na originalidade, mas no montante de redundância da ordem realizada» (op. cit., p. 129). 
Abstraindo, entretanto, desse aspecto terminológico mais estrito e tomando no caso, a palavra «estilo» como caracterizadora de estados estéticos regidos por determinados graus de ordem e repetição, é claro que há obras que podem desenvolver, de maneira inovadora, esse princípio estético.

Aliás, o estilo é um fato global, totalizante. Além disso, só tem sentido falar nele, não primariamente, mas em comparação com as formaspadrão da língua.

O confronto primordial deve ser sincrônico (sem excluir outros), isto é, dave fazer-se dentro de todo o sistema de escolhas do próprio autor, de sua concepção geral do fato estético.

No caso de Clarice Lispector, a repetição é assumida como «cantilena enjoada». Portanto, como som e ritmo, produzida pelo significante. É assumida como ritmo pessoal para dizer o que pode dizer a monotonia, a uniformidade fastidiosa de tom, num estilo que, por outro lado, tem sido acusado de sedução pelo verbal, ou elogiado como próximo da «melhor eloquiência barroca».

Essa «cantilena do significante» gera, no texto, o desgaste da palavra.

O silêncio que aí se anuncia não é silêncio amplificado, hiperbólico, da retórica. Também não parece um silêncio enfático. O discurso de Clarice aponta para o silêncio enquanto «grau zero» da escritura, porque, teoricamente, ela não acredita no poder da palavra. Aspirando a que a palavra diga o «ser» e concluindo que isso é impossível, Clarice vislumbra o silêncio, como única possibilidade de alcançar o indizível. No nível do discurso, o que para ela mais se aproxima desse silêncio é a repetição, como corrosão do próprio significante. Assim, por uma espécie de contrasenso, o que é normalmente redundante, acaba no contexto de sua obra, por abrir-se em sentido inovador. $\hat{E}$ um paradoxo desesperar tanto do signo verbal e votar-se a ele de maneira tão obsessiva e reiterante.

O itinerário que traça em $A$ Paixão segundo $G$. $H$. indica que a escritora recupera, pela renúncia à linguagem, a imersão nas coisas; o abraço sensorial do ser.

Se alguém, mesmo manipulando esteticamente a palavra, não encontra no código verbal recursos para uma expressão adequada de sua visão do mundo, isso postula um total ceticismo, em relação à eficácia do mesmo signo.

Clarice usa a repetição e o desgaste dos registros interjetivos para fazer minguar a linguagem. Entretanto, pela própria lógica dos significantes e pela consagração de Clarice à literatura (que é sempre uma forma), ela não pode impedir-se de provocar assim a geração de novos significados. 
Isto the valeu o epiteto de barroca. Diz Barthes que a geração moderna dos escritores se interessa pela comunicação segunda de que se investe a linguagem literária: o que é problemático hoje, não é a denotação, é a conotação ${ }^{38}$.

Clarice, em linguagem conotada, não questiona somente a literatura, isto é, a linguagem literária em si mesma ou a função social do escritor.

Ela se perdoa o não saber aproximar-se de um modo literário da «coisa social». Sua primeira verdade, antes mesmo da arte, foram os mocambos do Recife. «O problema da justiça é em mim um sentimento tão óbvio e tão básico que não consigo me surpreender com ele $-\mathrm{e}$, sem me surpreender, não consigo escrever» ${ }^{39}$.

Além disso, escrever para ela é procurar. O sentimento da justiça não é descoberta, é o óbvio. Ela, portanto, não se questiona e não se envergonha por não escrever, se envergonha por «não fazer».

O questionamento clariceano, expresso em ficção, é o da própria linguagem, enquanto capaz de denotar o ser. $\mathrm{O}$ que considera perigoso não é a linguagem conotativa. É o próprio ato de escrever, enquanto ato de nomear.

Clarice desconfia do "grau zero», embora sua escritura, por vezes, renteando o "barroquismo» tenha constantemente o silêncio em mira, como único capaz de permitir a adesão ao ser.

Claro que sua visada é fundamentalmente ontológica. Não questiona a realidade da matéria nem a do eu, enquanto ser produtor de linguagem. Questiona é a possibilidade subjetiva da linguagem e, portanto, a possibilidade do «eu» exprimir «a coisa». O nome é sempre um a mais, que se acrescenta ao ser. Se retomássemos a expressão de Barthes de que a função da literatura é «inexprimir o exprimível», isto é, tornar inovadores e originais os desgastados padrões da língua, para Clarice, a palavra é incapaz de atingir o inexpressivo. $\mathrm{O}$ indizivel não é o inefável, mas o inexpressivo.

No conto «O ovo e a galinha», a função poética se constrói no estranho enunciado desta evidência:

Com o tempo, o ovo se tornou um ovo de galinha. Não o é. Mas, adotado, usa-lhe o sobrenome. -Deve-se dizer «o ovo da galinha». Se se disser apenas «o ovo», esgota-se 0 assunto, e o mundo fica nu ${ }^{40}$.

${ }^{38}$ Cf. Barthes, Roland, Crítica e verdade (São Paulo: Perspectiva, 1970), p. 182.

${ }^{39}$ Clarice Lispector, $L E$, p. 149.

${ }^{40}$ Ibíd., p. 57. 
Designar o ser, sem mais, é muito perigoso. O ovo é branco. Mas não se pode dizer, simplesmente, que ele é branco. Isso pode destruir a humanidade.

A lei geral para continuarmos vivos: pode-se dizer «um rosto bonito», mas quem disser «o rosto» morre; por ter esgotado o assunto ${ }^{41}$.

Aumentar o assunto não significa, muitas vezes, desgastá-lo?

Desgastando-o pelo aumento, Clarice visa a despertar-nos para o repetitivo de todos os dias, que esconde de nós, como escondia de Joana, a sua verdadeira identidade não encontrada. A técnica da repetição de Clarice Lispector relaciona-se com o enfoque metalinguístico de sua obra. Joana, sem dúvida nenhuma, ressoa como uma réplica de Joana d'Arc. Quem disso duvidasse poderia ler as epígrafes de Uma aprendizagem. Uma delas é uma fala de Jeanne äArc au bûcher de Paul Claudel; donde se vê que em certo sentido a Lóri da Aprendizagem repete a primeira busca de Joana de Perto do coração selvagem: quem sou eu?

Joana d'Arc, a das vozes, é uma figura da escritora, questionando a sua própria voz. O que fascina Joana na famosa «mulher da voz» é a autenticidade de sua fala, que não se questiona, não se analisa, não se exprime, não se fala. Neste caso, ela acaba por problematizar a voz da narradora, que procura falar o mistério das coisas, que se analisa, presa na teia do seu dilema, pois não consegue formulá-lo sem recorrer às vozes, aos sons abstratos da linguagem, que lhe devoram a carne e a vida. Talvez por isso G. H. procure a comunhão com a barata. Devorando esse signo vivo de toda a matéria do mundo, ligado às raízes ancestrais do existir, ela busca solucionar o enigma: superar a tentação da linguagem, substituir-la pelo ícone repugnante do ser inteiriço, que não se deixa soletrar. Joana, a das vozes, intenta transformar-se em G. H., a da manducação direta do ser. Atinge assim uma espécie de afasia manducante. Essa tentativa brilhante de suprimir a linguagem e o outro está, porém, destinada ao fracasso; pelo menos para ela, Clarice. Enquanto escrever. Enquanto quiser dizer-se. Por isso à Paixão se segue a Aprendizagem, que instaura um processo de busca a dois, o único de toda a sua obra; onde o outro reaparece não alienante, onde a felicidade não é uma perda, onde Ulisses e Lóri, pelo amor, se transformam num só. Será de lamentar-se que o amor não seja ponto final, mas inaugure um novo discurso, indiciado pelos dois pontos? Ou será, antes, uma riqueza?

Evidencia-se como é importante, na obra de Clarice Lispector, a pers-

${ }^{41}$ Ibid., p. 57. 
pectiva metalinguística do narrador. Não só ele questiona o código, quando procura palavras no dicionário e declara que não sabia que na gíria a palavra «galinha» tinha outro sentido; mas questiona continuamente a própria narrativa, a essência do ato de escrever, enquanto é preciso usar palavras.

Se eu pudesse escrever por intermédio de desenhar na madeira ou de alisar uma cabeça de menino ou de passear pelo campo, jamais teria entrado pelo caminho da palavra. Faria o que tanta gente que não escreve faz, e exatamente com a mesma alegria e o mesmo tormento de quem escreve, e com as mesmas profundas decepções inconsoláveis: não usaria palavras ${ }^{42}$.

Serả talvez por isso que Clarice Lispector não inventa palavras:

Há muita coisa a dizer que não sei como dizer. Faltam as pàlavras. Mas recuso-me a inventar novas: as que existem já devem dizer o que se consegue dizer e o que é proibido ${ }^{43}$.

Ela cria ao nível da frase, ou melhor, une vocábulos; para lhes dar uma espécie de compacta individualidade, que não têm, quando separados: galinhas-que-não-sabiam-que-iam-morrer, poder-de-vida, que-é-que-eufaço, não-muda, sabor-a-ti, morte-sem-medo.

Apesar de sua consciência de que escrever se faz com palavras e se há de respeitar a natureza das sílabas, apesar de aspirar ao seco, ao inexpressivo, ao neutro da linguagem, Clarice Lispector não renuncia ao «de dentro» do homem e às palavras úmidas de que sua escritura coleante se nutre.

$\mathrm{O}$ amor entre duas baratas, matéria primordial, acontece vibrátil, ao sol do deserto da Líbia, sobre a rocha seca. O homem, mesmo que ame com «os olhos inteiramente abertos das baratas», tem de ser de noite.

... somos seres úmidos e salgados, somos seres de águas do mar e de lágrimas $(. .$.$) sou bicho de grandes profundidades úmidas, não conheço$ a poeira das cisternas secas, e a superficie de uma rocha não é o meu lar ${ }^{44}$.

\footnotetext{
${ }^{42}$ Ibid., p. 252.

${ }^{43}$ Clarice Lispector, Agua viva (Rio de Janeiro: Artenova, 1973), p. 34.

${ }^{44}$ Clarice Lispector, PSGH, p. 136.
} 